\title{
Analysis of Resistance to Eastern Filbert Blight in Corylus avellana
}

\author{
N. K. Osterbauer and K. B. Johnson, Department of Botany and Plant Pathology; S. A. Mehlenbacher, Depart- \\ ment of Horticulture; and T. L. Sawyer, Department of Botany and Plant Pathology, Oregon State University, Cor- \\ vallis $97331-2902$
}

\begin{abstract}
Osterbauer, N. K., Johnson, K. B., Mehlenbacher, S. A., and Sawyer, T. L. 1997. Analysis of resistance to eastern filbert blight in Corylus avellana. Plant Dis. 81:388-394.

Inheritance of resistance to eastern filbert blight, caused by Anisogramma anomala, in European hazelnut (Corylus avellana) was evaluated in the progeny of seven cultivars crossed in 12 combinations. The progeny were subjected to inoculation with $A$. anomala in the greenhouse and in the field. Three disease responses were measured: disease incidence, number of cankers, and proportion of wood diseased. In both the greenhouse and the field, progeny produced by crossing VR6-28 with three susceptible cultivars segregated 1:1 for complete resistance to eastern filbert blight, confirming a previous report that VR6-28 is heterozygous for a single, dominant resistance gene. Histograms of disease responses in progeny of the remaining six parents showed continuous distributions for all crosses examined. Consequently, these parents were analyzed for general and specific combining abilities for each disease response. In the field, general and specific combining ability were both significant $(P<0.05)$ for all disease responses, with general combining ability having twice the magnitude of specific combining ability. These results suggest these disease responses are controlled by additive gene action in the cultivars examined, with nonadditive gene action being of some importance. Based on general combining ability values, high levels of partial resistance were transmitted by the pollen parents, Gem and Tonda di Giffoni, and the seed parent, Willamette. Heritability of disease incidence, number of cankers, and proportion of wood diseased were calculated to be $0.21,0.39$, and 0.47 , respectively, for this set of nine crosses after the first exposure period in the field. This suggests that it will be possible to use partially resistant parents to breed for hazelnuts exhibiting fewer and smaller cankers.
\end{abstract}

Eastern filbert blight is a serious disease of European hazelnut (Corylus avellana L.) grown commercially in Oregon and Washington $(2,4,20)$. This disease was first detected in this area in 1970, when it was found in a commercial orchard located near Woodland, Washington (4). It is now firmly established in the northern one-third of Oregon's Willamette Valley, where $98 \%$ of U.S. hazelnut production occurs $(2,20)$. Eastern filbert blight is caused by Anisogramma anomala (Peck) E. Müller in E. Müller \& Arx, an ascomycetous fungus indigenous to the eastern United States (18). This fungus invades new, vegetative shoots in the spring and, after a period of tissue maturation and cold dormancy, forms stromata within a perennial canker $(7,21,27)$. Expansion of these cankers leads to girdling of branches and limbs, resulting in canopy dieback and tree death in 4 to 10 years.

Several control methods for eastern filbert blight have been examined, the most effective of which has been fungicide ap-

Corresponding author: K. B. Johnson

E-mail: johnsonk@bcc.orst.edu

Accepted for publication 14 January 1997.

Publication no. D-1997-0204-07R

(C) 1997 The American Phytopathological Society plications $(8,19,27)$. To completely prevent infection, the trees must be protected for a period of 2 months following leaf emergence each spring. This requires multiple fungicide applications, resulting in high costs for hazelnut growers (8). Cultural control methods, such as pruning, are only partially effective, thus limiting their value to growers (27). Consequently, breeding commercially acceptable cultivars resistant to eastern filbert blight is viewed as the most desirable method to limit this disease $(3,11,13,19)$.

In 1991, Mehlenbacher et al. reported that Gasaway, an obsolete pollenizer cultivar, carried a single, dominant gene for complete resistance to eastern filbert blight (13). This gene has since been transferred into several, more commercially acceptable germ plasm releases (12). In several other pathosystems, however, resistance controlled by a single, dominant gene has been overcome by a virulence shift in the pathogen (9). Therefore, identifying new sources of resistance to eastern filbert blight and determining the heritability of this resistance is necessary.

The susceptibility of several cultivars and clones of $C$. avellana and of other Corylus spp. to infection by $A$. anomala has been evaluated previously $(3,13,19)$. In addition to Gasaway, several other cultivars and Corylus spp. have shown nearly complete resistance to infection $(3,19)$.
Unfortunately, most of these resistant cultivars and species are not commercially acceptable. These resistant species and cultivars are being used to develop new cultivars resistant to eastern filbert blight $(10,11)$. The objective of this study was to evaluate the heritability of resistance to eastern filbert blight in seven European hazelnut cultivars.

\section{MATERIALS AND METHODS}

Plant material. Crosses were made between selected cultivars of $C$. avellana in 1991, as described previously (28). Trees of seed parents were emasculated in early December 1990 prior to female flower receptivity and enclosed in wooden frames covered with white polyethylene to exclude windborne pollen. Pollen was collected from male parents and stored in vials in the freezer $\left(-20^{\circ} \mathrm{C}\right)$ until needed. In February, when the flowers of the seed parents were fully receptive, they were pollinated by touching pollen onto the surface of the styles. The seed parents selected for this study were Ennis, a cultivar highly susceptible to eastern filbert blight, Willamette, a moderately susceptible cultivar, and Casina, another moderately susceptible cultivar (19). Pollen parents were Tonda Gentile delle Langhe, a highly susceptible cultivar, Tonda di Giffoni, a moderately susceptible cultivar, Gem, a resistant cultivar, and VR6-28 (Riccia di Talanico $\times$ Gasaway), a selection that carries a single, dominant gene for complete resistance $(12,13)$.

Nuts from the crosses were collected in late August 1991 and stratified at $4^{\circ} \mathrm{C}$ until the following spring (28). After germination, the nuts were planted in a mixture of peat and vermiculite $(1: 1, \mathrm{vol} / \mathrm{vol})$ in $3 \times 3$ $\times 5 \mathrm{~cm}$ cells and fertilized periodically with a water soluble fertilizer (20:20:20, $\mathrm{N}: \mathrm{P}: \mathrm{K})$. After 6 weeks, the seedlings were transplanted to a mix of peat, sand, and pumice $(1: 1: 2, \mathrm{vol} / \mathrm{vol} / \mathrm{vol})$ in $3 \times 3 \times 3 \mathrm{~cm}$ pots and treated with a slow release fertilizer $(14: 14: 14, \mathrm{~N}: \mathrm{P}: \mathrm{K})$. Seedlings for the greenhouse study were used immediately in experiments and maintained in $3 \times 3 \times 3$ $\mathrm{cm}$ pots. Those for the field study were transplanted to 4-liter pots and grown through the summer and fall of 1992 before being transferred to the Washington State University Experiment Station in Vancouver to overwinter. In March 1993, prior to the first period of exposure in the field, the trees were transplanted to 8-liter pots containing a mix of sandy loam, peat, 
sand, and pumice (1:1:1:2, vol/vol/vol/vol). Uninoculated trees from each cross were maintained at the Oregon State University Botany and Plant Pathology Field Laboratory located east of Corvallis, a location outside the current range of eastern filbert blight (19). Two-year-old trees of the parent cultivars also were exposed to $A$. anomala in the field. These trees were obtained from local nurseries and planted in 8-liter pots containing the same soil mix and fertilizer as that used for the progeny populations.

Experimental design. The greenhouse experiment was arranged in a completely randomized design, and trees were inoculated on two different sets of inoculation dates. Because only a limited number of seedlings was available from some crosses, the number of seedlings used per cross on an inoculation date ranged from a low of four to a high of 41 ; the mean number of seedlings inoculated per cross per date was 11. No seedlings were available from the cross Ennis $\times$ Gem for the greenhouse study. Data collected from the seedlings included disease incidence, total number of cankers, total length of diseased wood, and total seedling length. The latter measure was included in order to calculate proportion of wood diseased. Absence of infection in symptomless trees was confirmed by microscopic examination of hand sections taken from inoculated tissues $(7,19,27)$. This is the standard procedure for identifying nonsymptomatic infections by this obligately biotrophic parasite (27).

The field study was arranged in a randomized complete block design with three replicates. Each replicate included 15 trees from each cross. Nine trees of each parent were included in each replicate. Incidence of disease, total number of cankers, total length of diseased wood, and total tree length were measured for each tree.

Inoculation. Diseased hazelnut branches exhibiting cankers and mature stromata of A. anomala were collected in November 1991 and 1992, from a commercial orchard located near Boring, Oregon. Cankers collected in 1991 were used as a source of inoculum for the greenhouse study. Cankers collected in 1992 were used to inoculate trees in the first year of the field study. For the second year of the field study, diseased branches were collected from an abandoned orchard near Damascus, Oregon, in November 1993.

In the greenhouse study, a small drop of a latex grafting compound (Farewell Industries, Wenatchee, WA) was used to mark susceptible tissue behind the apical bud on a single shoot of an 8-week-old seedling 1 day prior to inoculation (7). After the latex dried, the seedling was inoculated by dipping the shoot in a suspension of $A$. anomala ascospores $(1 \times$ $10^{7}$ ) plus $0.02 \%$ activated charcoal for $3 \mathrm{~s}$ $(7,27)$. Inoculated and noninoculated (control) seedlings were placed in an intermit- tent mist chamber that applied mist for $15 \mathrm{~s}$ every $30 \mathrm{~min}$. Seedlings remained in the mist chamber for 5 days. Shoot inoculations were repeated three times over a period of 3 weeks for each set of inoculation dates, beginning 2 June 1992 for the first set and 20 July 1992 for the second set. After inoculation, the seedlings were moved to a greenhouse bench and maintained for 12 weeks in a controlled environment $\left(18^{\circ} \mathrm{C}\right.$ day, $13^{\circ} \mathrm{C}$ night). After this time, seedlings were moved to an unheated greenhouse at the North Willamette Research and Extension Center, Aurora, Oregon, to cycle through a natural period of cold dormancy; this is required for symptom expression and canker development (27). Disease responses were measured in June 1993.

In the field study, 1- to 2-year-old trees were inoculated as described previously (19) by exposing the potted trees under elevated, wire-mesh platforms $(3.3 \times 4.6$ $\mathrm{m})$ that held diseased hazelnut branches. During periods of rain and high humidity, ascospores were released from stromata contained within the cankers. The first period of exposure was from 12 March to 29 May 1993, and the second was from 17 March to 21 May 1994. In 1993, a supplemental sprinkler system was installed on each platform to enhance spore release during the exposure period and to irrigate the trees over the summer. Each spring, gutter-type traps (19) were placed under

Table 1. Mean incidence and severity of eastern filbert blight measured on the progeny of 12 crosses of seven European hazelnut cultivars inoculated with Anisogramma anomala in the greenhouse and in the field

\begin{tabular}{|c|c|c|c|c|c|c|c|c|}
\hline \multirow[b]{2}{*}{$\begin{array}{l}\text { Seed parent } \times \\
\text { pollen parent }\end{array}$} & \multicolumn{3}{|c|}{ Greenhouse } & \multicolumn{3}{|c|}{ Field year 1} & \multicolumn{2}{|c|}{ Field year $2^{a}$} \\
\hline & $\begin{array}{c}\text { Disease } \\
\text { incidence } \\
(\%)\end{array}$ & $\begin{array}{c}\text { Mean no. } \\
\text { cankers }\end{array}$ & $\begin{array}{c}\text { Mean prop. } \\
\text { diseased } \\
\text { wood }(\text { SD) }\end{array}$ & $\begin{array}{c}\text { Disease } \\
\text { incidence } \\
(\%)\end{array}$ & $\begin{array}{c}\text { Mean no. } \\
\text { cankers }\end{array}$ & $\begin{array}{l}\text { Mean prop. } \\
\text { diseased } \\
\text { wood (SD) }\end{array}$ & $\begin{array}{c}\text { Disease } \\
\text { incidence } \\
(\%)\end{array}$ & $\begin{array}{c}\text { Mean prop. } \\
\text { diseased } \\
\text { wood (SD) }\end{array}$ \\
\hline Ennis $\times \mathrm{TGDL}^{\mathrm{c}}$ & 93 & 0.9 & $\begin{array}{c}0.45 \\
( \pm 0.27)\end{array}$ & 98 & 7.8 & $\begin{array}{c}0.54 \\
( \pm 0.23)\end{array}$ & 100 & $\begin{array}{c}0.60 \\
( \pm 0.27)\end{array}$ \\
\hline Ennis $\times \mathrm{TDG}^{\mathrm{d}}$ & 100 & 0.9 & $\begin{array}{c}0.46 \\
( \pm 0.30)\end{array}$ & 94 & 6.7 & $\begin{array}{c}0.36 \\
( \pm 0.21)\end{array}$ & 95 & $\begin{array}{c}0.49 \\
( \pm 0.22)\end{array}$ \\
\hline Ennis $\times$ Gem & $\ldots^{\mathrm{e}}$ & $\ldots$ & $\ldots$ & 95 & 5.8 & $\begin{array}{c}0.35 \\
( \pm 0.23)\end{array}$ & 100 & $\begin{array}{c}0.49 \\
( \pm 0.25)\end{array}$ \\
\hline Ennis $\times$ VR6-28 & 33 & 0.4 & $\begin{array}{c}0.24 \\
( \pm 0.26)\end{array}$ & 58 & 3.6 & $\begin{array}{c}0.16 \\
( \pm 0.20)\end{array}$ & 55 & $\begin{array}{c}0.23 \\
( \pm 0.27)\end{array}$ \\
\hline Willamette $\times$ TGDL & 98 & 1.2 & $\begin{array}{c}0.52 \\
( \pm 0.19)\end{array}$ & 100 & 7.7 & $\begin{array}{c}0.54 \\
( \pm 0.23)\end{array}$ & 100 & $\begin{array}{c}0.64 \\
( \pm 0.28)\end{array}$ \\
\hline Willamette $\times$ TDG & 97 & 0.8 & $\begin{array}{c}0.38 \\
( \pm 0.26)\end{array}$ & 86 & 4.6 & $\begin{array}{c}0.23 \\
( \pm 0.17)\end{array}$ & 87 & $\begin{array}{c}0.40 \\
( \pm 0.28)\end{array}$ \\
\hline Willamette $\times$ Gem & 82 & 0.6 & $\begin{array}{c}0.29 \\
( \pm 0.28)\end{array}$ & 81 & 3.4 & $\begin{array}{c}0.15 \\
( \pm 0.13)\end{array}$ & 94 & $\begin{array}{c}0.30 \\
( \pm 0.25)\end{array}$ \\
\hline Willamette $\times$ VR6-28 & 45 & 0.4 & $\begin{array}{c}0.22 \\
( \pm 0.21)\end{array}$ & 42 & 1.4 & $\begin{array}{c}0.05 \\
( \pm 0.08)\end{array}$ & 47 & $\begin{array}{c}0.08 \\
( \pm 0.13)\end{array}$ \\
\hline Casina $\times$ TGDL & 84 & 1.0 & $\begin{array}{c}0.34 \\
( \pm 0.30)\end{array}$ & 95 & 6.5 & $\begin{array}{c}0.36 \\
( \pm 0.19)\end{array}$ & 95 & $\begin{array}{c}0.55 \\
( \pm 0.27)\end{array}$ \\
\hline Casina $\times$ TDG & 75 & 0.8 & $\begin{array}{c}0.35 \\
( \pm 0.22)\end{array}$ & 100 & 7.7 & $\begin{array}{c}0.39 \\
( \pm 0.19)\end{array}$ & 100 & $\begin{array}{c}0.51 \\
( \pm 0.24)\end{array}$ \\
\hline Casina $\times$ Gem & 100 & 0.8 & $\begin{array}{c}0.46 \\
( \pm 0.17)\end{array}$ & 94 & 6.5 & $\begin{array}{c}0.33 \\
( \pm 0.22)\end{array}$ & 97 & $\begin{array}{c}0.11 \\
( \pm 0.20)\end{array}$ \\
\hline Casina $\times$ VR6-28 & 38 & 0.4 & $\begin{array}{c}0.21 \\
( \pm 0.20)\end{array}$ & 41 & 1.6 & $\begin{array}{c}0.06 \\
( \pm 0.12)\end{array}$ & 31 & $\begin{array}{c}0.44 \\
( \pm 0.24)\end{array}$ \\
\hline
\end{tabular}

${ }^{a}$ Mean number of cankers was not calculated for field year 2 because of merging of cankers from the previous year.

${ }^{\mathrm{b}}$ Standard deviation.

${ }^{c}$ Pollen parent Tonda Gentile delle Langhe.

d Pollen parent Tonda di Giffoni.

e No value was obtained. 
each platform to collect spores that washed from the diseased branches overhead. The concentration of ascospores in the wash was estimated as described previously $(19,27)$. Disease responses were measured on the trees 16 months after each exposure period. The trees were maintained in pots until the end of the second exposure period, then were transplanted into a field of sandy loam soil located on the experiment station.

Data analyses. Values for disease incidence, number of cankers, and proportion of wood diseased were summarized for each cross. Number of cankers could not be summarized for the second year of the field study because of merging of cankers from the previous year. For crosses that involved the pollen parent VR6-28, the incidence of disease in individual seedlings was subjected to chi-square $\left(\chi^{2}\right)$ analysis using Yates' correction factor (5) to determine if the progeny segregated $1: 1$ for susceptibility and complete resistance. For all crosses, frequency distributions of the proportion of wood diseased and the number of cankers on individual trees were constructed. In those crosses where individual trees exhibited a continuous range of disease responses, the parent cultivars were subjected to combining ability analysis.

General combining abilities for six parents (excluding VR6-28) were calculated using the disease responses measured in the greenhouse seedlings and in trees from

Table 2. Mean incidence and severity of eastern filbert blight measured on seven cultivars of European hazelnut inoculated with Anisogramma anomala in the field

\begin{tabular}{|c|c|c|c|c|c|}
\hline \multirow[b]{2}{*}{ Cultivar } & \multicolumn{3}{|c|}{ Field year 1} & \multicolumn{2}{|c|}{ Field year $2^{\mathrm{a}}$} \\
\hline & $\begin{array}{c}\text { Disease } \\
\text { incidence } \\
(\%)\end{array}$ & $\begin{array}{c}\text { Mean no. } \\
\text { cankers }\end{array}$ & $\begin{array}{c}\text { Mean prop. } \\
\text { diseased } \\
\operatorname{wood}(S D)^{b}\end{array}$ & $\begin{array}{c}\text { Disease } \\
\text { incidence } \\
(\%)\end{array}$ & $\begin{array}{c}\text { Mean prop. } \\
\text { diseased } \\
\text { wood (SD) }\end{array}$ \\
\hline Ennis & 90 & 4 & $\begin{array}{c}0.22 \\
( \pm 0.15)\end{array}$ & 100 & $\begin{array}{c}0.38 \\
( \pm 0.20)\end{array}$ \\
\hline Willamette & 77 & 2 & $\begin{array}{c}0.07 \\
( \pm 0.07)\end{array}$ & 87 & $\begin{array}{c}0.18 \\
( \pm 0.11)\end{array}$ \\
\hline Casina & 83 & 4 & $\begin{array}{c}0.23 \\
( \pm 0.15)\end{array}$ & 97 & $\begin{array}{c}0.39 \\
( \pm 0.20)\end{array}$ \\
\hline TGDL $^{c}$ & 87 & 3 & $\begin{array}{c}0.32 \\
( \pm 0.18)\end{array}$ & 82 & $\begin{array}{c}0.36 \\
( \pm 0.25)\end{array}$ \\
\hline $\mathrm{TDG}^{\mathrm{d}}$ & 41 & 1 & $\begin{array}{c}0.04 \\
( \pm 0.08)\end{array}$ & 37 & $\begin{array}{c}0.02 \\
( \pm 0.03)\end{array}$ \\
\hline Gem & 30 & 2 & $\begin{array}{c}0.08 \\
( \pm 0.15)\end{array}$ & 50 & $\begin{array}{c}0.13 \\
( \pm 0.23)\end{array}$ \\
\hline VR6-28 & 0 & 0 & $\begin{array}{c}0.00 \\
( \pm 0.00)\end{array}$ & 0 & $\begin{array}{c}0.00 \\
( \pm 0.00)\end{array}$ \\
\hline $\mathrm{LSD}^{\mathrm{e}}$ & 24 & 2 & 0.07 & 25 & 0.14 \\
\hline
\end{tabular}

a Mean number of cankers was not calculated for field year 2 because of merging of cankers from the previous year.

${ }^{\mathrm{b}}$ Standard deviation.

c Tonda Gentile delle Langhe.

d Tonda di Giffoni.

${ }^{\mathrm{e}}$ Least significant difference. the field study (25). General combining ability measures the average performance of a parent in a series of crosses for a particular trait and is considered a measure of additive gene action $(6,25)$. General combining ability was determined by comparing the mean value of all progeny of a parent for a particular disease response to the grand mean for that disease response averaged across all crosses used in the analysis. For each disease response, the specific combining ability values for each cross were calculated by subtracting the observed disease response from the expected disease response (25). The expected disease response for each cross was obtained by adding the general combining ability estimates of the parents to the grand mean for that disease response. For example, if the grand mean for number of cankers was 2.5 , and the general combining ability estimates for the seed and pollen parents were -1.0 and +0.5 , respectively, the expected value for the progeny would equal 2.0. Specific combining ability is indicative of nonadditive gene action $(6,25)$. For the missing Ennis $\times$ Gem cross in the greenhouse study, values for disease incidence, mean number of cankers, and mean proportion of wood diseased were estimated by a least-squares method (26). Disease response variables were subjected to analysis of variance using parent cultivars as the independent variables to determine the significance of general and specific combining abilities in each study. The model statement for this analysis was:

$$
X_{\mathrm{SP}}=X^{\prime}+G_{\mathrm{S}}+G_{\mathrm{P}}+S_{\mathrm{SP}}+E
$$

where $X_{\mathrm{SP}}$ is the mean progeny disease response for cross $\mathrm{S} \times \mathrm{P}, X^{\prime}$ is the grand mean for all crosses, $G_{\mathrm{S}}$ and $G_{\mathrm{P}}$ are the general combining abilities of the seed and pollen parents, respectively, $S_{\mathrm{SP}}$ is the specific combining ability, and $E$ is the residual error $(24,25)$.

Table 3. Segregation analysis for incidence of eastern filbert blight, caused by Anisogramma anomala, in progeny populations of the resistant European hazelnut selection VR6-28 and three susceptible cultivars for inoculations conducted in the greenhouse and field

\begin{tabular}{|c|c|c|c|c|c|c|c|}
\hline \multirow[b]{2}{*}{ Study } & \multirow[b]{2}{*}{ Cross } & \multicolumn{2}{|c|}{ Number of progeny } & \multirow[b]{2}{*}{ Expected ratio } & \multicolumn{3}{|c|}{$\chi^{2}$} \\
\hline & & Nondiseased & Diseased & & Value & df & $P$ value \\
\hline Greenhouse & $\begin{array}{l}\text { Ennis } \times \text { VR6-28 } \\
\text { Will. }^{\mathrm{a}} \times \text { VR6-28 } \\
\text { Casina } \times \text { VR6-28 } \\
\text { Pooled }^{\mathrm{b}} \\
\text { Homogeneity }^{\mathrm{c}}\end{array}$ & $\begin{array}{l}22 \\
24 \\
25 \\
71\end{array}$ & $\begin{array}{l}11 \\
25 \\
15 \\
51\end{array}$ & $\begin{array}{l}1: 1 \\
1: 1 \\
1: 1\end{array}$ & $\begin{array}{l}3.03 \\
0.00 \\
2.03 \\
2.96 \\
2.10\end{array}$ & $\begin{array}{l}1 \\
1 \\
1 \\
1 \\
2\end{array}$ & $\begin{array}{l}0.10-0.05 \\
0.99-0.95 \\
0.25-0.10 \\
0.25-0.10 \\
0.50-0.25\end{array}$ \\
\hline Field year 1 & $\begin{array}{l}\text { Ennis } \times \text { VR6-28 } \\
\text { Will. } \times \text { VR6-28 } \\
\text { Casina } \times \text { VR6-28 } \\
\text { Pooled } \\
\text { Homogeneity }\end{array}$ & $\begin{array}{l}18 \\
26 \\
24 \\
68\end{array}$ & $\begin{array}{l}27 \\
19 \\
20 \\
66\end{array}$ & $\begin{array}{l}1: 1 \\
1: 1 \\
1: 1\end{array}$ & $\begin{array}{l}1.42 \\
0.08 \\
0.02 \\
0.01 \\
2.41\end{array}$ & $\begin{array}{l}1 \\
1 \\
1 \\
1 \\
2\end{array}$ & $\begin{array}{l}0.25-0.10 \\
0.50-0.25 \\
0.75-0.50 \\
0.95-0.90 \\
0.50-0.25\end{array}$ \\
\hline Field year 2 & $\begin{array}{l}\text { Ennis } \times \text { VR6-28 } \\
\text { Will. } \times \text { VR6-28 } \\
\text { Casina } \times \text { VR6-28 } \\
\text { Pooled } \\
\text { Homogeneity }\end{array}$ & $\begin{array}{l}19 \\
23 \\
28 \\
70\end{array}$ & $\begin{array}{l}24 \\
21 \\
13 \\
58\end{array}$ & $\begin{array}{l}1: 1 \\
1: 1 \\
1: 1\end{array}$ & $\begin{array}{l}0.37 \\
0.02 \\
4.78 \\
0.95 \\
4.22\end{array}$ & $\begin{array}{l}1 \\
1 \\
1 \\
1 \\
2\end{array}$ & $\begin{array}{l}0.75-0.50 \\
0.90-0.75 \\
0.05-0.01 \\
0.75-0.50 \\
0.25-0.10\end{array}$ \\
\hline
\end{tabular}

\footnotetext{
a Seed parent Willamette.

b Total of nondiseased and diseased plants for all three crosses combined.

c The homogeneity of ratio for the pooled results.
} 
Estimates of heritability for disease incidence, number of cankers, and proportion of wood diseased were calculated using data collected after the first exposure period in the field, as described by Hartl (6). Data from crosses with VR6-28 were excluded from this analysis. The mean disease responses for each cross were regressed on the midparent disease responses; the midparent disease response equaled the average of the two parental mean values for that disease response. The regression coefficient is considered an estimate of heritability for that disease response (6).

\section{RESULTS}

In the greenhouse, $78 \%$ of the seedlings from all 12 crosses inoculated with $A$. anomala ascospores developed symptoms of eastern filbert blight (Table 1). Diseased seedlings had an average of one canker per seedling and a mean proportion of wood diseased of 0.36 .

In the field, potted trees were exposed to an average of $2.3 \times 10^{7}$ ascospores/ $\mathrm{m}^{2} /$ week from 12 March to 29 May 1993. During the second exposure period, from 17 March to 31 May 1994, trees were exposed to an average of $1.2 \times 10^{7}$ ascospores $/ \mathrm{m}^{2} /$ week. Eighty-two percent of the potted trees became diseased after the first exposure period (Table 1). Diseased trees exhibited an average of five cankers per tree and a mean proportion of wood diseased of 0.29 . After the second exposure period, $84 \%$ of the potted trees were dis- eased, and diseased trees exhibited an average proportion of wood diseased of 0.40 .

For trees of the parental cultivars, an average disease incidence of $59 \%$ was observed in the field (Table 2). Diseased trees

Table 4. Analysis of variance of combining ability in Corylus avellana for three disease responses to eastern filbert blight, caused by Anisogramma anomala, collected in the greenhouse study, after the first exposure to disease in the field, and after the second exposure to disease in the field

\begin{tabular}{|c|c|c|c|c|c|}
\hline & \multirow[b]{2}{*}{ Source } & \multirow[b]{2}{*}{ df } & \multicolumn{3}{|c|}{ Mean squares } \\
\hline & & & $\begin{array}{c}\text { Disease } \\
\text { incidence }\end{array}$ & $\begin{array}{l}\text { Mean no. } \\
\text { cankers }\end{array}$ & $\begin{array}{l}\text { Mean prop. } \\
\text { diseased wood }\end{array}$ \\
\hline Greenhouse & $\begin{array}{l}\text { Experiment } \\
\text { Seed GCA } \\
\text { Pollen GCA } \\
\text { Seed } \times \text { pollen } \mathrm{SCA}^{\mathrm{b}} \\
\text { Error }^{\mathrm{d}}\end{array}$ & $\begin{array}{l}1 \\
2 \\
2 \\
4 \\
4\end{array}$ & $\begin{array}{c}47.68 \\
94.66 \\
10.53 \\
169.53 * \mathrm{c} \\
24.37\end{array}$ & $\begin{array}{l}0.050 \\
0.001 \\
0.051 \\
0.075 \\
0.021\end{array}$ & $\begin{array}{l}0.002 \\
0.007 \\
0.006 \\
0.014 \\
0.005\end{array}$ \\
\hline Field year 1 & $\begin{array}{l}\text { Experiment } \\
\text { Seed GCA } \\
\text { Pollen GCA } \\
\text { Seed } \times \text { pollen SCA } \\
\text { Error }\end{array}$ & $\begin{array}{r}2 \\
2 \\
2 \\
4 \\
16\end{array}$ & $\begin{array}{c}77.93 \\
146.18^{* *} \\
149.20^{* *} \\
99.22^{*} \\
23.39\end{array}$ & $\begin{array}{r}19.086^{* *} \\
6.296^{* *} \\
10.415^{* *} \\
4.007^{*} \\
0.965\end{array}$ & $\begin{array}{l}0.008 \\
0.028 * \\
0.099 * * \\
0.030 * \\
0.005\end{array}$ \\
\hline Field year 2 & $\begin{array}{l}\text { Experiment } \\
\text { Seed GCA } \\
\text { Pollen GCA } \\
\text { Seed } \times \text { pollen SCA } \\
\text { Error }\end{array}$ & $\begin{array}{r}2 \\
2 \\
2 \\
4 \\
16\end{array}$ & $\begin{array}{l}19.52 \\
48.64 \\
40.62 \\
55.34 * \\
17.53\end{array}$ & $\begin{array}{l}\mathrm{NA}^{\mathrm{e}} \\
\mathrm{NA} \\
\mathrm{NA} \\
\mathrm{NA} \\
\mathrm{NA}\end{array}$ & $\begin{array}{l}0.003 \\
0.014^{* *} \\
0.086^{* *} \\
0.014^{* *} \\
0.001\end{array}$ \\
\hline
\end{tabular}

a General combining ability.

b Specific combining ability.

c *,** significant at the $P \leq 0.05$ and $P \leq 0.01$ probability level, respectively.

$\mathrm{d}$ The error term accounts for environmental interaction (e.g., block $\times$ cross).

e No values were available for analysis.

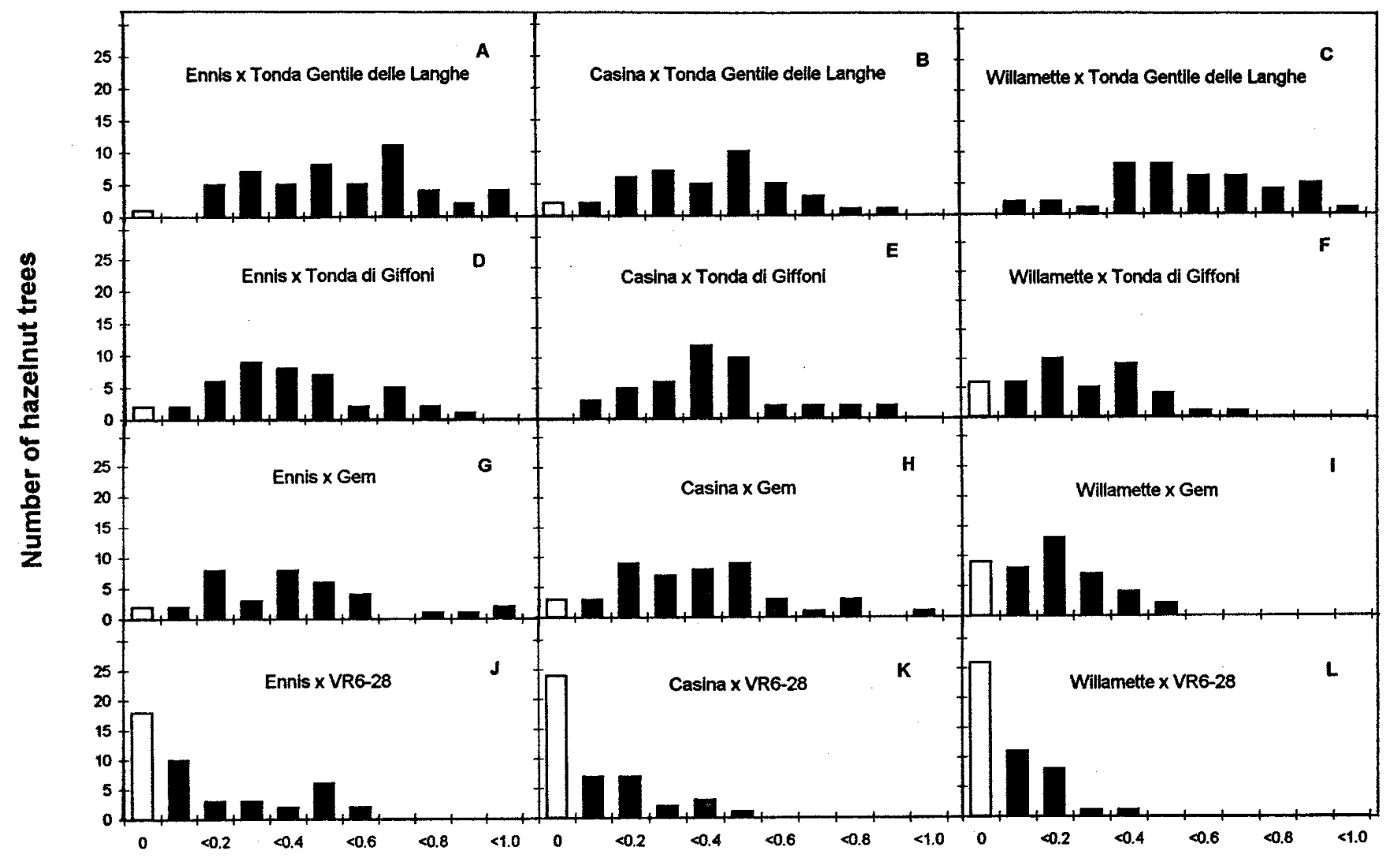

\section{Frequency classes for proportion of wood diseased}

Fig. 1. Histograms showing the frequency distribution for proportion of wood diseased with eastern filbert blight, caused by Anisogramma anomala, in the progeny of three seed parental cultivars and four pollen parental cultivars of European hazelnut crossed in all combinations. Results presented are from data collected from the progeny after the first year of exposure in the field. 
averaged two cankers per tree and a mean proportion of wood diseased of 0.14. After the second exposure period, mean disease incidence increased to $65 \%$ and mean proportion of wood diseased to 0.21 . No disease was observed on VR6-28 (Table 2). Disease was observed on trees of the remaining six cultivars. All three disease responses were significantly lower $(P \leq$ $0.05)$ in cultivars Gem and Tonda di Giffoni when compared to cultivars Ennis, Casina, and Tonda Gentile delle Langhe (Table 2). Willamette also had a low mean number of cankers and mean proportion of wood diseased, but a high incidence of disease was observed (77\%) (Table 2).

Complete resistance. In the greenhouse and field studies, progeny from crosses with the pollen parent VR6-28 were examined for inheritance of a single, dominant gene for complete resistance. For the greenhouse study, disease incidence in seedlings combined across all three crosses did not deviate significantly from the expected ratio of one nondiseased (resistant) seedling to one diseased (susceptible) seedling (pooled $\chi^{2}=2.96$ with $1 \mathrm{df}$ ) (Table 3) (14). Similar results were obtained for the first and second years of the field study (pooled $\chi^{2}=0.01$ with $1 \mathrm{df}$, and pooled $\chi^{2}=0.95$ with $1 \mathrm{df}$, respectively) (Table 3) (15). In the second year, the ratio of nondiseased to diseased trees differed from 1:1 for cross Casina $\times$ VR6-28 (Table 3 ) because four trees that were diseased the first year were symptomless the following year and because three diseased trees from the first year of the field study were missing the following year. For all three crosses combined, the progeny did not deviate significantly from an expected ratio of one diseased offspring to one nondiseased offspring in either year of the field study (pooled $\chi^{2}=0.95$ with $1 \mathrm{df}$ ) (Table 3 ).

Partial resistance. The frequency distributions for proportion of wood diseased for all 12 crosses examined in this study are shown in Figure 1. The histograms showed a continuous range of disease responses observed in the progeny from nine crosses, suggesting resistance in these crosses may be controlled quantitatively. The progeny from crosses with certain parents (e.g., Willamette) had consistently low levels of disease with small standard deviations (Fig. 1C, F, I, and L; Table 1), whereas the progeny of other parents (e.g., Tonda Gentile delle Langhe; Fig. 1A to C) showed a much broader range of responses. Number of cankers per tree also showed frequency distributions similar to those in Figure 1 for all crosses (data not shown).

Combining ability analysis was performed on the parents whose progeny exhibited a continuous range of responses to infection by $A$. anomala; this excluded progeny from crosses that involved VR628. These progeny were examined for disease incidence, mean number of cankers, and mean proportion of wood diseased (Table 1), and general combining abilities for the parents were calculated for each disease response. Analysis of variance was performed on the disease responses observed in the progeny to determine the significance of general and specific combining ability in these parents (Table 4). General combining ability was not significant $(P>0.05)$ for any of the disease responses examined in the greenhouse, whereas specific combining ability was significant $(P \leq 0.05)$ for disease incidence (Table 4). In contrast, both general and specific combining ability were significant $(P \leq 0.05)$ for all disease responses measured after the first year of the field study (Table 4). For each disease response, general combining ability was nearly twice the magnitude of specific combining ability. Specific combining ability was significant for both disease incidence $(P \leq 0.05)$ and mean proportion of wood diseased $(P \leq$ 0.01 ) in field year 2 , while general combining ability was significant only for mean proportion of wood diseased $(P \leq$ 0.01) (Table 4).

In the first year of the field study, progeny of the pollen parents, Tonda di Giffoni (general combining ability estimate [GCA] $=-0.33$ ) and Gem (GCA $=-3.93)$, had lower levels of disease incidence than the grand mean for all crosses. This also was true for progeny of the seed parent Willamette $(\mathrm{GCA}=-4.63)$ (Table 5). The fewest cankers were observed on progeny of Gem (GCA $=-1.08)$ and on progeny of Willamette $(\mathrm{GCA}=-1.05)$. Proportions of wood diseased that were lower than the grand mean were observed on progeny of Gem, Tonda di Giffoni, and Willamette (Table 5) (15). The general ranking of Gem, Tonda di Giffoni, and Willamette as parents capable of transmitting high levels of partial disease resistance to their progeny did not change from the first to the second year of the field study (Table 5).

Specific combining ability, as measured by the difference between an observed mean disease response for a cross and an expected value based on the estimated general combining ability values of the parents, was important in a few crosses,

Table 5. General combining ability (GCA) estimates for six European hazelnut cultivars based on eastern filbert blight incidence and severity in progeny populations inoculated with Anisogramma anomala in the greenhouse and for two consecutive years in the field

\begin{tabular}{|c|c|c|c|c|c|c|}
\hline \multirow[b]{2}{*}{ Study } & \multicolumn{2}{|c|}{ Disease incidence } & \multicolumn{2}{|c|}{ Mean no. cankers } & \multicolumn{2}{|c|}{ Mean prop. diseased wood } \\
\hline & Cultivar & GCA & Cultivar & GCA & Cultivar & GCA \\
\hline Greenhouse & $\begin{array}{c}\text { Casina } \\
\text { TDG }^{\mathrm{b}} \\
\text { TGDL }^{\mathrm{c}} \\
\text { Gem } \\
\text { Will. }^{\mathrm{d}} \\
\text { Ennis }\end{array}$ & $\begin{array}{l}-5.17^{\mathrm{a}} \\
-0.67 \\
+0.17 \\
+0.40 \\
+0.87 \\
+4.20\end{array}$ & $\begin{array}{l}\text { TDG } \\
\text { Gem } \\
\text { Casina } \\
\text { Ennis } \\
\text { Will. } \\
\text { TGDL }\end{array}$ & $\begin{array}{c}-0.04 \\
-0.04 \\
0.00 \\
0.00 \\
+0.01 \\
+0.10\end{array}$ & $\begin{array}{c}\text { Casina } \\
\text { Gem } \\
\text { Will. } \\
\text { TDG } \\
\text { Ennis } \\
\text { TGDL }\end{array}$ & $\begin{array}{l}-0.02 \\
-0.02 \\
-0.01 \\
-0.01 \\
+0.03 \\
+0.03\end{array}$ \\
\hline Field year 1 & $\begin{array}{l}\text { Will. } \\
\text { Gem } \\
\text { TDG } \\
\text { Ennis } \\
\text { Casina } \\
\text { TGDL }\end{array}$ & $\begin{array}{l}-4.63 \\
-3.93 \\
-0.33 \\
+1.83 \\
+2.73 \\
+4.20\end{array}$ & $\begin{array}{l}\text { Gem } \\
\text { Will. } \\
\text { TDG } \\
\text { Ennis } \\
\text { Casina } \\
\text { TGDL }\end{array}$ & $\begin{array}{l}-1.08 \\
-1.05 \\
+0.02 \\
+0.45 \\
+0.61 \\
+1.06\end{array}$ & $\begin{array}{c}\text { Gem } \\
\text { Will. } \\
\text { TDG } \\
\text { Casina } \\
\text { Ennis } \\
\text { TGDL }\end{array}$ & $\begin{array}{r}-0.09 \\
-0.05 \\
-0.03 \\
0.00 \\
+0.06 \\
+0.12\end{array}$ \\
\hline Field year 2 & $\begin{array}{l}\text { Will. } \\
\text { TDG } \\
\text { Gem } \\
\text { Casina } \\
\text { Ennis } \\
\text { TGDL }\end{array}$ & $\begin{array}{l}-2.60 \\
-2.33 \\
+0.70 \\
+0.97 \\
+1.77 \\
+1.77\end{array}$ & $\begin{array}{l}\mathrm{NA}^{\mathrm{e}} \\
\mathrm{NA} \\
\mathrm{NA} \\
\mathrm{NA} \\
\mathrm{NA} \\
\mathrm{NA}\end{array}$ & $\begin{array}{l}\text { NA } \\
\text { NA } \\
\text { NA } \\
\text { NA } \\
\text { NA } \\
\text { NA }\end{array}$ & $\begin{array}{l}\text { Gem } \\
\text { Will. } \\
\text { TDG } \\
\text { Casina } \\
\text { Ennis } \\
\text { TGDL }\end{array}$ & $\begin{array}{l}-0.08 \\
-0.04 \\
-0.03 \\
+0.01 \\
+0.04 \\
+0.11\end{array}$ \\
\hline
\end{tabular}

a A negative general combining ability estimate indicates a mean disease response lower than the grand mean for all crosses was detected in the progeny of this parent.

b Tonda di Giffoni.

c Tonda Gentile delle Langhe.

d Willamette.

e No values were available for analysis. 
such as Willamette $\times$ Gem and Willamette $\times$ Tonda di Giffoni (Fig. 2). In other crosses (e.g., Ennis $\times$ Tonda Gentile delle Langhe), specific combining ability was of little importance.

The estimate of heritability for number of cankers per tree was $0.39( \pm 0.02)$ for cultivars Ennis, Willamette, Casina, Tonda Gentile delle Langhe, Tonda di Giffoni, and Gem. The estimate of heritability for proportion of wood diseased was 0.47 $( \pm 0.04)$ and for disease incidence was 0.21 $( \pm 0.05)$ for these same cultivars.

\section{DISCUSSION}

The results of this study show that partial resistance to eastern filbert blight is a moderately heritable trait in C. avellana, the European hazelnut. The heritability levels calculated for disease incidence, number of cankers per tree, and proportion of wood diseased are consistent with those calculated for other traits observed in $C$. avellana (10). The progeny of cultivars Gem and Willamette, and to a lesser extent, Tonda di Giffoni, showed relatively high levels of partial resistance to eastern filbert blight. The significance and magnitude of general combining ability relative to specific combining ability suggest this partial resistance to eastern filbert blight is controlled mainly by additive gene action.

The selection VR6-28, a pollen parent examined in this study, is an offspring of Gasaway, a cultivar that carries a single, dominant gene for complete resistance to eastern filbert blight (13). Progeny from all crosses with VR6-28 segregated 1:1 for complete resistance to this disease in both the greenhouse and the field. These results show that progeny of VR6-28 inherited the Gasaway resistance gene from VR6-28 in a single, dominant fashion. In 1995, Coyne backcrossed resistant Gasaway progeny with Gasaway and obtained a 3:1 ratio of resistant to susceptible seedlings (3). Her results, combined with the results reported here, support the conclusion that the Gasaway resistance gene is inherited in a single, dominant fashion (13). Thus, European hazelnut possesses both qualitative (major gene) and quantitative resistance to eastern filbert blight.

Disease responses measured on progeny seedlings inoculated with $A$. anomala in the greenhouse differed from those measured on 1- to 2-year-old progeny inoculated in the field. For example, in the greenhouse, progeny of the seed parent Casina had low values for disease incidence, number of cankers, and proportion of wood diseased (Table 1). In the field, however, the progeny of this cultivar were much more susceptible to eastern filbert blight (Table 1). As a result, the general combining ability values for each disease response in cultivar Casina changed from the greenhouse to the field (Table 5). This phenomenon occurred in cultivars Willamette and Gem as well. These results suggest that greenhouse inoculation of young, vegetative seedlings may not be suitable for identifying parents that transmit high levels of partial disease resistance to their progeny. A similar problem was encountered in a study of the heritability of fire blight resistance in crosses of pear cultivars (22). The results of the study showed that disease responses were weakly correlated between plants inoculated in the greenhouse and plants inoculated in the field (22). Fortunately, the heritability estimates for number of cankers per tree and proportion of wood diseased after 1 year of exposure in the field were moderately high in European hazelnut. This suggests that for the purposes of applied breeding, the phenotype of the parent is an adequate predictor of the parent's general combining ability. Progeny testing in the field need only be done when more accurate measures of combining ability are required.

The level of disease detected in several parental cultivars was similar to that reported earlier (19). Cultivars Ennis and Tonda Gentile delle Langhe were highly susceptible to eastern filbert blight, cultivars Willamette and Tonda di Giffoni were moderately susceptible, and selection VR628 was completely resistant. However, the level of disease observed in two cultivars, Gem and Casina, differed from previous reports $(3,19)$. Casina has been reported to be a moderately susceptible cultivar (19) but was considered highly susceptible to eastern filbert blight in this study. No disease was detected on Gem trees in the previous report (19), but $30 \%$ of the trees included in this study became infected with eastern filbert blight. Our results match observations made within an orchard of mixed cultivars in which eastern filbert blight was allowed to develop naturally. In this orchard, eastern filbert blight was observed on $100 \%$ of the Casina trees and on $11 \%$ of the Gem trees (S. A. Mehlenbacher and D. Smith, unpublished). Our inoculation conditions were somewhat more stringent than in the previous studies $(3,19)$. Apparently, inoculation of Gem and Casina with large quantities of spores continuously over several years diminishes the effectiveness of the partial disease resistance observed in these two cultivars.

In other pathosystems, partial disease resistance in a host may be controlled by one to several genes $(1,16,17,29)$. For example, resistance to fire blight in pears is apparently quantitative (22). When a frequency distribution of progeny disease responses in pear progenies was constructed, a continuous range of responses was observed (22). Similar to disease responses in pear progenies, the frequency distribution for proportion of wood diseased for European hazelnut progenies was mostly continuous over the range of responses observed (Fig. $1)$. Only disease responses in progeny of VR6-28 were dramatically skewed toward one end of the range, in this case toward no disease (Fig. $1 \mathrm{~J}$ to $\mathrm{L}$ ). This skewing pattern suggests the presence of a dominant gene for resistance, whereas the continuous range of susceptible responses suggests that multiple genes are involved. In a recent paper by Pinkerton et al., the response of $C$. avellana to infection by $A$. anomala was examined at the microscopic level (21). Their conclusions state that successful infection by the pathogen is dependent on several factors, including structural characteristics of the epidermis and cuticle,

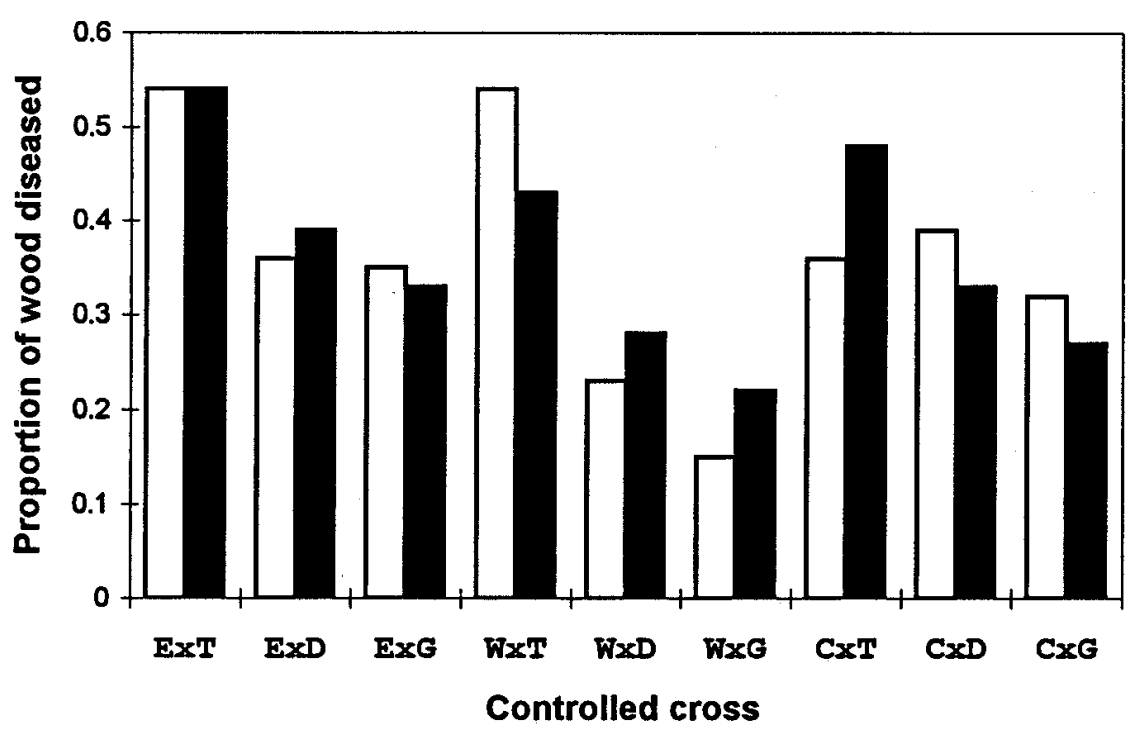

Fig. 2. Observed mean proportion of wood diseased (open bar) with eastern filbert blight, caused by Anisogramma anomala, in progeny populations from nine crosses of European hazelnut cultivars compared with an expected proportion of wood diseased (solid bar) based on the estimated general combining abilities of each parent in a cross. The difference between observed and expected values is the measure of specific combining ability. Standard deviations for the observed values are reported in Table 1. Parentage of the crosses is indicated as follows: $\mathrm{E}=$ Ennis, $\mathrm{W}=$ Willamette, $\mathrm{C}=\mathrm{Casina}, \mathrm{T}=$ Tonda Gentile delle Langhe, $\mathrm{D}=$ Tonda di Giffoni, and $\mathrm{G}=\mathrm{Gem}$. 
cell vacuolation, and accumulation of fungitoxic substances. These factors are the result of plant growth and development, traits normally under multigenic control (23). This would be consistent with our observations that partial resistance is inherited quantitatively and is controlled primarily by additive gene action. A more extensive study must be done on the interaction of host and parasite in this system to better elucidate the mechanisms of partial disease resistance in $C$. avellana.

Gasaway, the cultivar from which the single, dominant gene for complete resistance was identified, can become diseased with eastern filbert blight when $A$. anomala cankers grow across a graft union with a diseased scion cultivar (21). These results suggest this single, dominant gene plays a role in preventing initial infection by ascospores of the pathogen.

Specific combining ability, a measure of nonadditive gene action (dominance and epistasis), was significant $(P \leq 0.05)$ for all disease responses measured in this study (Table 4). This suggests dominant genes other than the Gasaway gene may exist that determine how the host, European hazelnut, reacts to infection by $A$. anomala. Specific combining ability, however, was of lesser magnitude than general combining ability (Table 4).

Combining partial resistance with resistance controlled by a single, dominant gene is considered a good strategy for increasing the longevity of dominant resistance genes in the field (9). Such resistance combinations should prevent severe disease outbreaks should the dominant resistance gene be rendered ineffective by a virulence shift in the pathogen (9). Only one dominant gene for complete resistance to A. anomala has been identified in European hazelnut (13). Results from this study show that the high levels of partial resistance observed in some cultivars, as expressed by fewer and smaller cankers, is heritable. VR6-28, a selection that carries the dominant gene for complete resistance, also may be a potential source of high levels of partial resistance for hazelnut breeders. The progeny of VR6-28 that were diseased tended to have fewer, smaller cankers than the diseased progeny of other parents (Fig. 1J to L). In conclusion, it should be possible to breed new cultivars with increased levels of partial resistance to eastern filbert blight. Growing these new, partially resis- tant cultivars with cultivars carrying the single, dominant resistance gene for complete resistance may present a durable strategy for combating this devastating disease.

\section{ACKNOWLEDGMENTS}

We thank J. Dileone, J. Glass, S. Gaudreault, and D. Smith for their technical assistance. This research was supported in part by the USDA Agricultural Research Service and Oregon Agricultural Experiment Station Specific Cooperative Agreement 58-5358-190 and the Oregon Hazelnut Commission. This is technical paper 11,038 of the Oregon Agricultural Experiment Station.

\section{LITERATURE CITED}

1. Bing, J. W., Guthrie, W. D., and Dicke, F. F. 1992. Genetics of resistance in maize to the corn leaf aphid. J. Econ. Entomol. 85:14761479.

2. Cameron, H. R. 1976. Eastern filbert blight established in the Pacific Northwest. Plant Dis. Rep. 60:737-740.

3. Coyne, C. J. 1995. Genetic resistance to eastern filbert blight. Ph.D. thesis. Oregon State University, Corvallis.

4. Davidson, A. R., and Davidson, R. M., Jr. 1973. Apioporthe and Monochaetia cankers reported in western Washington. Plant Dis. Rep. 57:522-523.

5. Gomez, K. A., and Gomez, A. A. 1984. Statistical Procedures for Agricultural Research. 2nd ed. John Wiley \& Sons, New York.

6. Hartl, D. L. 1988. A Primer of Population Genetics. Sinauer Associates, Sunderland, MA.

7. Johnson, K. B., Pinkerton, J. N., Gaudreault, S. M., and Stone, J. K. 1994. Infection of European hazelnut by Anisogramma anomala: Site of infection and effect of host developmental stage. Phytopathology 84:1465-1470.

8. Johnson, K. B., Pscheidt, J. W., and Pinkerton, J. N. 1993. Evaluation of chlorothalonil, fenarimol, and flusilazole for control of eastern filbert blight. Plant Dis. 77:831-837.

9. Kiyosawa, S. 1986. Breakdown of blast resistance in rice in relation to general strategies of resistance gene deployment to prolong effectiveness of disease resistance in plants. Pages 251-282 in: Plant Disease Epidemiology: Genetics, Resistance, and Management. Vol. 2. K. J. Leonard and W. E. Fry, eds. McGraw-Hill Publishing Co., San Francisco.

10. Mehlenbacher, S. A. 1991. Genetic resources of temperate fruit and nut crops: Hazelnuts. Acta Hortic. 290:791-836.

11. Mehlenbacher, S. A. 1994. Genetic improvement of the hazelnut. Acta Hortic. 351:23-38.

12. Mehlenbacher, S. A., and Thompson, M. M. 1991. Four hazelnut pollenizers resistant to eastern filbert blight. HortScience 26:442443.

13. Mehlenbacher, S. A., Thompson, M. M., and Cameron, H. R. 1991. Occurrence and inheritance of resistance to eastern filbert blight in Gasaway hazelnut. HortScience 26:410-
411.

14. Osterbauer, N. K., Sawyer, T. L., Mehlenbacher, S. A., and Johnson, K. B. 1994. Combining ability analysis of resistance to eastern filbert blight in selected hazelnut cultivars. (Abstr.) Phytopathology 84:1117.

15. Osterbauer, N. K., Sawyer, T. L., Mehlenbacher, S. A., and Johnson, K. B. 1995. Analysis of resistance to eastern filbert blight in selected hazelnut cultivars. (Abstr.) Phytopathology 85:1177.

16. Parlevliet, J. E. 1979. Components of resistance that reduce the rate of epidemic development. Annu. Rev. Phytopathol. 17:203-222.

17. Parlevliet, J. E. 1986. Identification an evaluation of quantitative resistance. Pages 215-248 in: Plant Disease Epidemiology: Genetics, Resistance, and Management. Vol. 2. K. J. Leonard and W. E. Fry, eds. McGrawHill Publishing Co., San Francisco.

18. Peck, C. H. 1876. Diatrype anomala. Rep. New York State Mus. 28:72.

19. Pinkerton, J. N., Johnson, K. B., Mehlenbacher, S. A., and Pscheidt, J. W. 1993. Susceptibility of European hazelnut clones to eastern filbert blight. Plant Dis. 77:261-266.

20. Pinkerton, J. N., Johnson, K. B., Theiling, K. M., and Griesbach, J. A. 1992. Distribution and characteristics of the eastern filbert blight epidemic in western Oregon. Plant Dis. 76:1179-1182.

21. Pinkerton, J. N., Stone, J. K., Nelson, S. J., and Johnson, K. B. 1995. Infection of European hazelnut by Anisogramma anomala: Ascospore adhesion, mode of penetration of immature shoots, and host response. Phytopathology 85:1260-1268.

22. Quamme, H. A., Kappel, F., and Hall, J. W. 1990. Efficacy of early selection for fire blight resistance and the analysis of combining ability for fire blight resistance in several pear progenies. Can. J. Plant Sci. 70:905-913.

23. Salisbury, F. B., and Ross, C. W. 1985. Pages 290-446 in: Plant Physiology. 3rd ed. Wadsworth Publishing Co., Belmont, CA.

24. SAS Institute. 1988. SAS/STAT User's Guide, Release 6.03 ed. SAS Institute, Cary, NC.

25. Simmonds, N. W. 1979. Principles of Crop Improvement. Longman, New York. pp. 110116.

26. Steel, R. G. D., and Torrie, J. H. 1980. Principles and Procedures of Statistics: A Biometrical Approach. 2nd ed. McGraw-Hill Publishing Co., San Francisco.

27. Stone, J. K., Johnson, K. B., Pinkerton, J. N., and Pscheidt, J. W. 1992. Natural infection period and susceptibility of vegetative seedlings of European hazelnut to Anisogramma anomala. Plant Dis. 76:348-352.

28. Thompson, M. M., Lagerstedt, H. B., and Mehlenbacher, S. A. 1996. Hazelnuts. Pages 125-184 in: Fruit Breeding. Vol. 3, Nuts. J. Janick and J. N. Moor, eds. John Wiley \& Sons, New York.

29. Topp, B. L., Sherman, W. B., Huber, D. A., and Linda, S. B. 1993. Combining abilities of five Japanese plum cultivars for resistance to Xanthomonas canker. HortScience 28:727729. 